\title{
Glosso - Pharyngeal Breathing
}

\author{
MARGARET P. BAKER, M.C.S.P., M.A.P.A., \\ Senior Plyssiotherapist, Royal Children's Hospital, Orthopaedic Section, Mt. Eliza, Victoria, .Australia. \\ (Reproduced by kind permission of "Physiotherapy" Journal of Chartered Society of Physiotherapy, May, 1958 \\ and the Author.)
}

$T^{T}$ HE problem of how to increase the Vital Capacity of patients with severe and increasing scoliosis who require spine grafts has been a puzzling one.

Their initial low Vital Capacity is usually diminished after application of a Risser jacket, and further diminished as correction proceeds. The expanded lung on the convex side becomes restricted, while the contracted lung tissue on the concave side is stretched out and called on to do more work.

The latter is non-elastic through disuse, and requires powerful respiratory muscles to utilize it efficiently.

In January, 1956, I first heard of Glosso-Pharangeal Breathing (G.P.B.) being used in the Respirator Ward at Fairfield Hospital for Infectious Diseases, Melbourne, and promptly paid a visit there. 1 received a great deal of help and instruction from the physiotherapists and patients and came away very heartened by the atmosphere of hope and expectation in those hitherto chronic wards.

A new era is dawning for respirator cases and courageous efforts are being made by staff and patients to enable endless days in a respirator to come to an end.

G.P.B. is performed by the patient filling the mouth cavity with air, closing the mouth and nasal apertures, an forcing the air into the lungs using the larynx as a pump. This is called 'striking' and after several strokes the air in the lungs is released and that volume is the Tidal Volume.

Sometimes there occurs a leakage of air from the nasal apertures due to the patient being unable to close these by raising the soft plate, and in these cases the patient has to hold his nose tightly.

I was rather diffident at attempting to teach G.P.B. to children. However, our first two patients were co-operative and intelligent girls of ten and eleven years respectively. They were both in plaster jackets, but by means of diagrams and the practice of prescribed exercises they mastered the art of stroking in a remarkably short time.

Our aim in using G.P.B. was to gain maximum inspiration to stretch the lung tissue, thereby facilitating the work of the deficient respiratory muscles.

Patients have a pre-jacket routine, and as far as physiotherapy is concerned, this consists of: weekly vital capacity readings, breathing and mobilizing exercises, head suspension, muscle tests, swimming, and learning to 'frog' or G.P.B.

It is desirable for patients to master 'frogging' before the plaster jacket is applied, but so far all have mastered the technique even if they have not been proficient before having their plaster jackets on.

We now have a tradition of 'frogging' and the 'old hands' help the new boys and girls and take a pride in seeing how quickly their pupils can master it.

The patients inspire as deeply as possible using their respiratory muscles, and then stroke as many times as they can before releasing the air in the lungs. This procedure we term a 'blow-out.' The number of strokes varies very much with each patient; some complain of vertigo and these cases are discouraged from taking their maximum number of strokes.

Patients perform three blow-outs daily before doing ordinary breathing exercises. It was found that the best time for thesę exercises was just before a meal when the stomach was empty, as the constriction of the plaster prevents expansion of the stomach and lungs simultaneously.

G.P.B. is also used to stimulate the cough reflex after operation, which assists in the expectoration of mucus.

So far our results have been promising. All patients have increased their Vital Capacity and in a few cases doubled it.

On discharge patients have, been urged to continue their daily blow-outs and so keep or increase their Vital Capacities, thus aiding their oxygen intake and improving their general health.

They can also take advantage of the decrease in the mechanical constriction of the lungs brought about by the correction of the scoliosis.

Cases of scoliosis too severe for operation have been helped by this method to improve their Vital Capacities. The question arises as to whether we should teach all patients with markedly diminished V.C.'s to perform daily blow-outs as a routine measure. Personally, I think it would be well worth while.

\begin{tabular}{|c|c|c|c|}
\hline $\begin{array}{c}C A S E 1 . \\
\text { (T.G.) } \\
\text { Dale }\end{array}$ & $\begin{array}{l}\text { Admitted } \\
5.4 .56 \\
\text { V.C. }\end{array}$ & $\begin{array}{l}\text { Discharged } \\
28.3 .57 \\
\text { V.C. }+ \text { G.P.B. }\end{array}$ & $\begin{array}{l}\text { Age } 15 \text { years } \\
R E M A R K S\end{array}$ \\
\hline 24.4 .56 & $2200 \mathrm{ccs}$ & & Lying supine \\
\hline 30.4 .56 & 2200 & J 100 & Only learning G.P.B. \\
\hline $\begin{array}{l}30.7 .56 \\
21.8 .56\end{array}$ & 2300 & 3100 & Spinrgraft \\
\hline $\begin{array}{r}27.8 .56 \\
26.11 .56\end{array}$ & $\begin{array}{l}2200 \\
2700\end{array}$ & $\begin{array}{l}3200 \\
3500\end{array}$ & \\
\hline 28.3 .57 & 2500 & 3000 & $\begin{array}{l}\text { Out of plaster, lying } \\
\text { DISCHARGED }\end{array}$ \\
\hline $\begin{array}{c}\text { CASE } 2 . \\
\text { (C.W.) } \\
\text { Dale }\end{array}$ & $\begin{array}{l}\text { Admitted } \\
20.10 .55 \\
\text { V.C. }\end{array}$ & $\begin{array}{c}\text { Discharged } \\
5.11 .56 \\
\text { V.C. }-+ \text { G.P.B. }\end{array}$ & $\begin{array}{l}\text { Age } 10 \text { years } \\
R E M A R K S\end{array}$ \\
\hline $\begin{array}{l}16.1 .56 \\
29.2 .56 \\
13.3 .56\end{array}$ & $\begin{array}{l}800 \\
800\end{array}$ & 1000 & $\begin{array}{l}\text { Lying in plaster jacket } \\
\text { Lying out of plaster } \\
\text { Spine graft }\end{array}$ \\
\hline 30.4 .56 & 1000 & 1050 & \\
\hline $\begin{array}{l}31.7 .56 \\
11.9 .56\end{array}$ & 1400 & 1400 & Plaster jucket removed \\
\hline 3.10 .56 & 1500 & 1600 & In block leather jacket \\
\hline $\begin{array}{c}\text { CASE 3. } \\
\text { Date }\end{array}$ & $\begin{array}{l}\text { Admited } \\
6.6 .56 \\
\text { V.C. }\end{array}$ & $\begin{array}{c}\text { Discharged } \\
12.6 .57 \\
\text { V.C. }+ \text { G.P.B. }\end{array}$ & $\begin{array}{l}\text { Age } 15 \text { years } \\
R E M A R K S\end{array}$ \\
\hline $\begin{array}{r}9.7 .56 \\
3.8 .56 \\
17.9 .56 \\
23.10 .56\end{array}$ & $\begin{array}{l}2200 \\
2000 \\
2200\end{array}$ & & $\begin{array}{l}\text { Lying supine } \\
\text { Lying supine } \\
\text { Lying supine } \\
\text { Spine graft }\end{array}$ \\
\hline 30.10 .56 & 1500 & & \\
\hline $\begin{array}{r}4.12 .56 \\
7.1 .57 \\
5.2 .57 \\
2.4 .57\end{array}$ & $\begin{array}{l}2100 \\
2200 \\
2500 \\
2100\end{array}$ & $\begin{array}{l}2600 \\
2800 \\
3000 \\
2700\end{array}$ & Patient slow to learn GPB \\
\hline $\begin{array}{l}13.5 .57 \\
16.5 .57 \\
12.6 .57\end{array}$ & 2400 & 2900 & $\begin{array}{l}\text { Plaster removed } \\
\text { Lying out of plaster } \\
\text { DISCHARGED }\end{array}$ \\
\hline $\begin{array}{c}C A S E 4 . \\
\text { (J.S.) } \\
\text { Date }\end{array}$ & $\begin{array}{l}\text { Admitted } \\
10.11 .55 \\
\text { V.C. }\end{array}$ & $\begin{array}{c}\text { Discharged } \\
14.12 .56 \\
\text { V.C.+G.P.B. }\end{array}$ & $\begin{array}{l}\text { Age } 10 \text { years } \\
R E M A R K S\end{array}$ \\
\hline 16.1 .56 & 600 & & $\begin{array}{l}\text { Lying supine in plaster } \\
\text { jacket }\end{array}$ \\
\hline 29.2 .56 & 700 & & $\begin{array}{l}\text { Lying supine out of } \\
\text { plaster jacket }\end{array}$ \\
\hline $\begin{array}{r}9.3 .56 \\
23.3 .56\end{array}$ & 600 & 700 & Spine graft ist stage \\
\hline 11.4 .56 & 800 & 900 & \\
\hline $\begin{array}{r}11.5 .56 \\
4.6 .56 \\
4.8 .56\end{array}$ & $\begin{array}{l}1300 \\
1400\end{array}$ & $\begin{array}{l}1100 \\
1500\end{array}$ & Spine graft 2nd stage \\
\hline 22.11 .56 & 1100 & 1200 & $\begin{array}{l}\text { Risser jacket removed, } \\
\text { light plaster jacket } \\
\text { applied } \\
\text { DISCHARGED }\end{array}$ \\
\hline
\end{tabular}




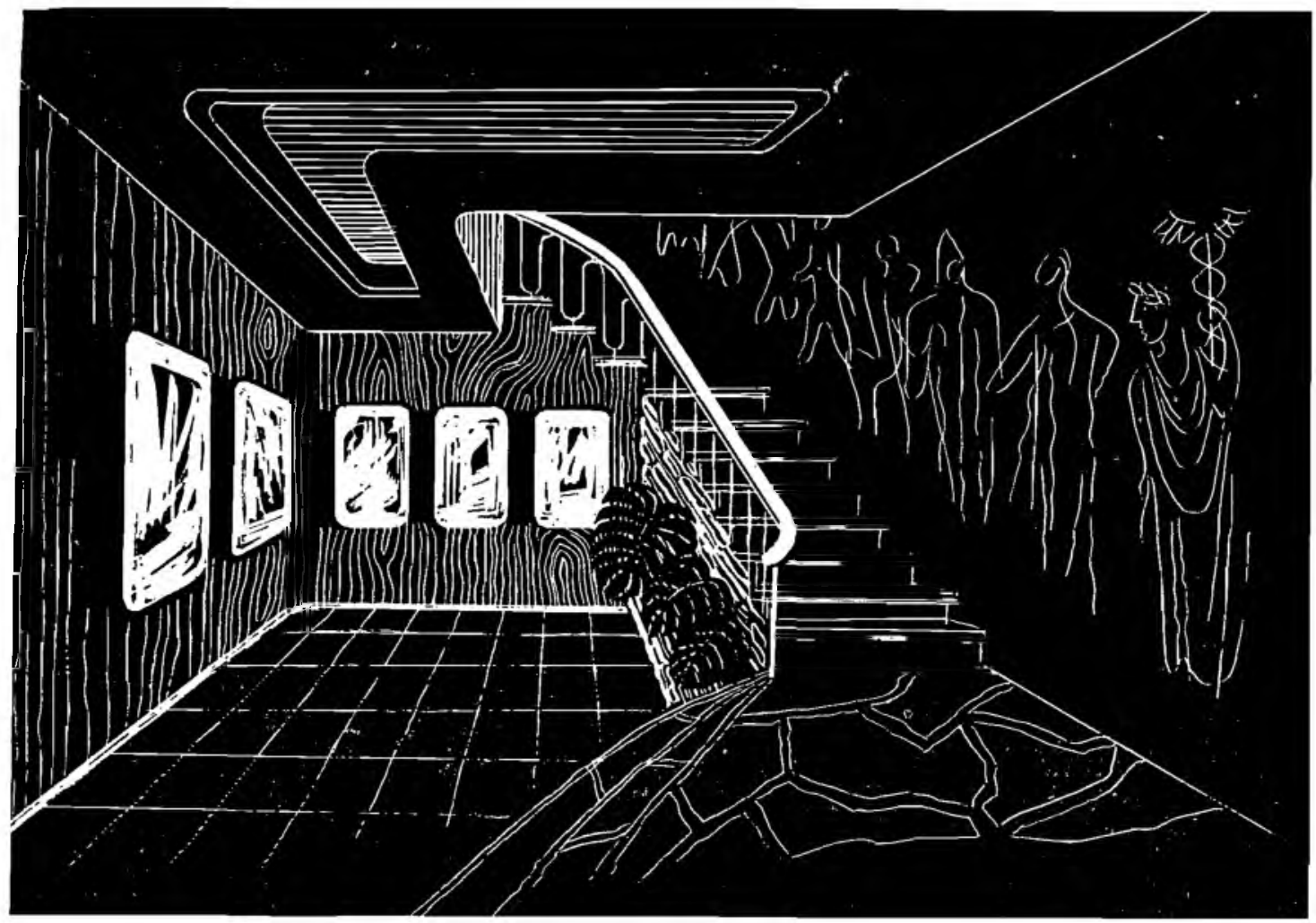

Ingang tot ons nuwe perseel, Jeppestraat 252, Johannesburg.

\section{Wat is 'n Ingang?}

Ons glo dat 'n ingang meer is as net 'n deur of 'n opening waardeur 'n mens toegang tot'n perseel kry.

Vir ons is dit 'n weerspieëling van die gees van die eienaars, die atmosfeer wat daar binne heers en die lewensbeskouing van die persone wat u gaan ontmoet.

Mag ons u vriendelik uitnooi om ons 'n besoek te bring by ons nuwe perseel te ,CAPE-YORK', Jeppestraat 252, geleë tussen Goud- en Nuggetstrate, Johannesburg?

Die ingang is in Jeppestraat, op die grondverdieping, derde winkel van die hoek van Goudstraat. Sodra die gebou voltooi is sal daar voldoende parkeerplek wees. In die tussentyd druk asseblief die ,Parkeerknoppie' in die ingangsportaal en u kar sal veilig versorg word terwyl u deur ons vertoonkamer luier.
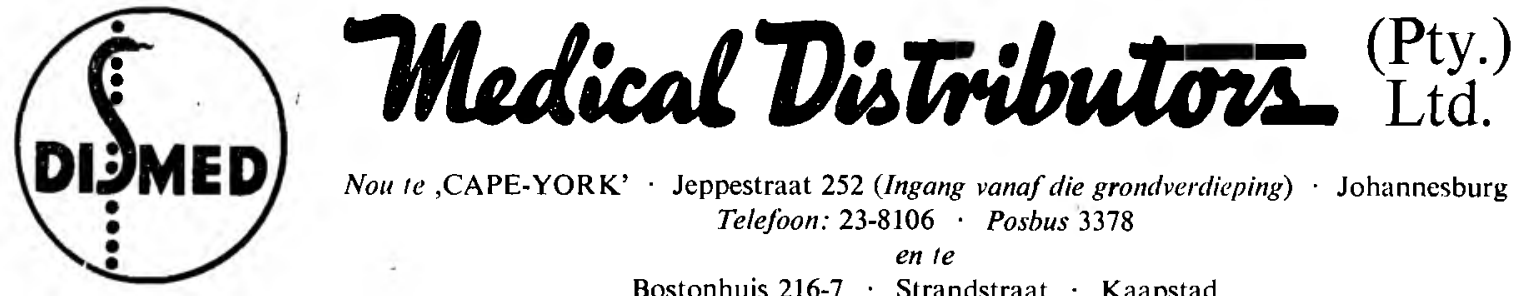

Nou te ,CAPE-YORK' · Jeppestraat 252 (Ingang vanaf die grondverdieping) - Johannesburg Telefoon: 23-8106. Posbus 3378

en te

Bostonhuis 216-7 - Strandstraat - Kaapstad

Telefoon: $3-4608$ 